DOI: 10.35784/IAPGOS.227

\title{
DIAGNOSTIC OF THE COMBUSTION PROCESS USING THE ANALYSIS OF CHANGES IN FLAME LUMINOSITY
}

\author{
Żaklin Grądz ${ }^{1}$, Joanna Styczeń ${ }^{2}$ \\ ${ }^{1}$ Lublin University of Technology, Institute of Electronics and Information Technology, Lublin, Poland, \\ ${ }^{2}$ Lublin University of Technology, Department of Construction, Lublin, Poland
}

\begin{abstract}
Monitoring of the combustion process is carried out in order to ensure its efficiency and stability. Selected aspects of the combustion process diagnostics using the analysis of changes in flame luminosity for two configurations: $100 \%$ pulverized coal fuel and a mixture of $80 \%$ coal and $20 \%$ biomass were presented in the article. The analysis of measurement data was conducted using selected statistical tools and a multiresolution analysis
\end{abstract} of signals.

Keywords: combustion process, multiresolution analysis, flame luminosity

\section{DIAGNOSTYKA PROCESU SPALANIA Z WYKORZYSTANIEM ANALIZY ZMIAN INTENSYWNOŚCI ŚWIECENIA PLOMIENIA}

Streszczenie. Monitoring procesu spalania jest prowadzony w celu zapewnienia efektywności i stabilności przebiegu procesu. W artykule przedstawiono wybrane aspekty diagnostyki procesu spalania z wykorzystaniem analizy sygnałów intensywności świecenia płomienia dla dwóch konfiguracji: paliwa w postaci $100 \%$ pytu węlowego i mieszaniny $80 \%$ wegla z 20\% biomasa. Analiza danych pomiarowych została przeprowadzone z wykorzystaniem wybranych narzędzi statystycznych oraz analizy wielorozdzielczej sygnałów.

Słowa kluczowe: proces spalania, analiza wielorozdzielcza, intensywność świecenia płomienia

\section{Introduction}

Energy production in the Polish energy sector is mainly based on fossil fuels. During their processing, is pollutants - including sulfur and nitrogen oxides - are released into the atmosphere. In the European Union member countries, there are legal regulations that determine the permissible limits for the emission of pollutants, exhaust gases and particulate matter. Their main goal is a broadly understood environmental protection, especially mitigating the greenhouse effect, smog and acid rains. The combustion process must be conducted under optimal conditions, i.e. having no negative impact on the process efficiency and the amount of produced pollutants $[6,10]$. Numerous factors, such as: the amount of primary or secondary air or the composition of the fuel mixture, may disrupt the efficiency of the combustion process. Therefore, selection of the appropriate diagnostic method is extremely important. The main aim of the process diagnostic is an early detection of malfunction symptoms and distinguishing between these states. Such actions enable to prevent the disruption of a correctly conducted process, economic losses resulting from prospective malfunctions and improve the protection of the natural environment [5].

The diagnostic methods of the combustion process frequently involve the optical methods - belonging to the group of noninvasive methods. The monitoring systems based on optical methods acquire and process the information recorded during the process in real-time. During the monitoring of fuel mixture combustion in a combustion chamber, an optical probe is placed directly adjacent to the burner. Such solution enables to obtain the best diagnostic parameters and the information located in the flame luminosity and its spectrum. The changes in the combustion process are also dependent on the type of fuel mixture $[1,4,8,15]$.

Direct combustion of pulverized coal is carried out by the stream of primary and secondary air. Primary air us used for the transportation of pulverized coal to the burner; simultaneously, its flux is adjusted to ensure stability of the flame. In the case of the secondary air, it is introduced to the flame in the further part of the burner. Direct combustion is the basic coal combustion technology, which is constantly being studied to reduced the amount of generated pollutants $[6,12,14]$.

Co-combustion of coal and biomass is the process in which coal is burned with appropriately selected solid biofuels. Biomass is a significant renewable energy source, since it is virtually inert for the natural environment during its processing. Carbon dioxide is produced during its combustion, which is subsequently absorbed by plants in the course of photosynthesis. The co-combustion of biomass may be carried out in three ways: through directly, indirectly and parallel. In the case of direct combustion, coal and biomass form a mixture and are burned in a single combustion chamber. The complexity of the co-combustion process requires the application of monitoring and diagnostic methods especially accounting for the process stability and safety $[2,3,9]$.

\section{Combustion process monitoring system}

The analysis of the combustion process, regardless of whether it is carried out under industrial or experimental conditions, necessitates employing specialist measurement systems. A system for monitoring the changes in flame luminosity was designed and built at the Institute of Electronics and Information Technology, Lublin University of Technology [7, 11, 13]. The measurements carried out using this device are non-invasive for the combustion process, while the acquired measurement data are transmitted without latency. Figure 1 shows a scheme of the diagnostic system.

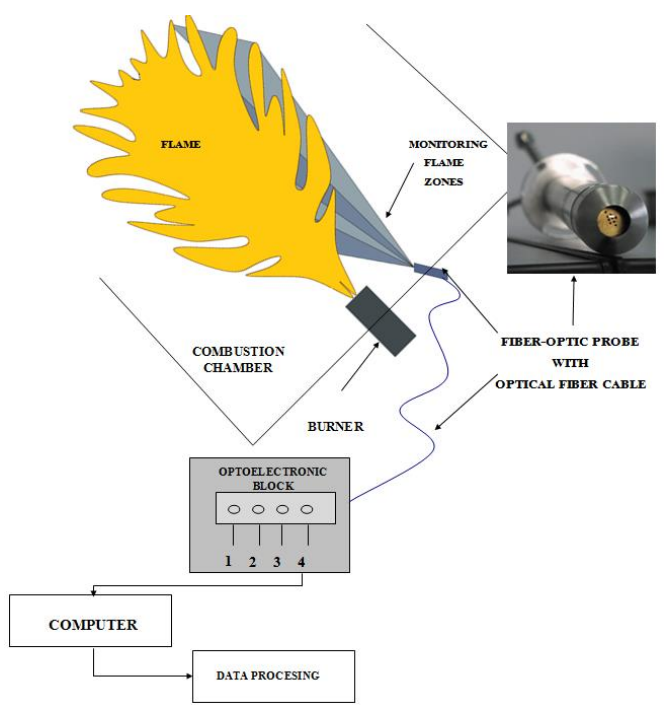

Fig. 1. Flame monitoring system

The diagnostic system comprises such elements as: optical fiber measurement probe, photodetectors and optoelectronic block. In order to gather the measurement data from the flame, the head 
of the optical fiber probe is inserted to the combustion chamber through an orifice. Then, the measurement data recorded in the form of optical signal are sent using optical fiber bundles to the optoelectronic block. The block consists of four identical signal paths - channels 1-4 - which enable monitoring different flame zones. Additionally, the optical signals in the optoelectronic block are processed into electric signals, which enables their further processing.

\section{Analysis of measurement data}

The paper presents the analysis of measurement data variability of flame luminosity obtained from the combustion process conducted for two fuel types:

- $100 \%$ pulverized coal and

- mixture of $80 \%$ coal and $20 \%$ biomass.

The measurement data were recorded on a research setup at the Institute of Power Engineering at constant parameters:

- thermal power $-400 \mathrm{~kW}$,

- excess air coefficient $\lambda=0.85$.

For both variants, the measurement time and the number of collected samples were the same. The characteristics of changes in flame luminosity for pure coal and its mixture with biomass were presented below (Figures 2 and 4, respectively). While conducting measurements for each of the presented configurations, 2457600 samples were obtained. Such amount of data enables a general assessment of the process; thus, the analyzed signals were divided into five areas, i.e. 'A'-'E'. It was assumed that each area will comprise 524288 samples.

The histograms presented for particular 'A'-'E' areas of both measurement variants show the frequency distribution pertaining
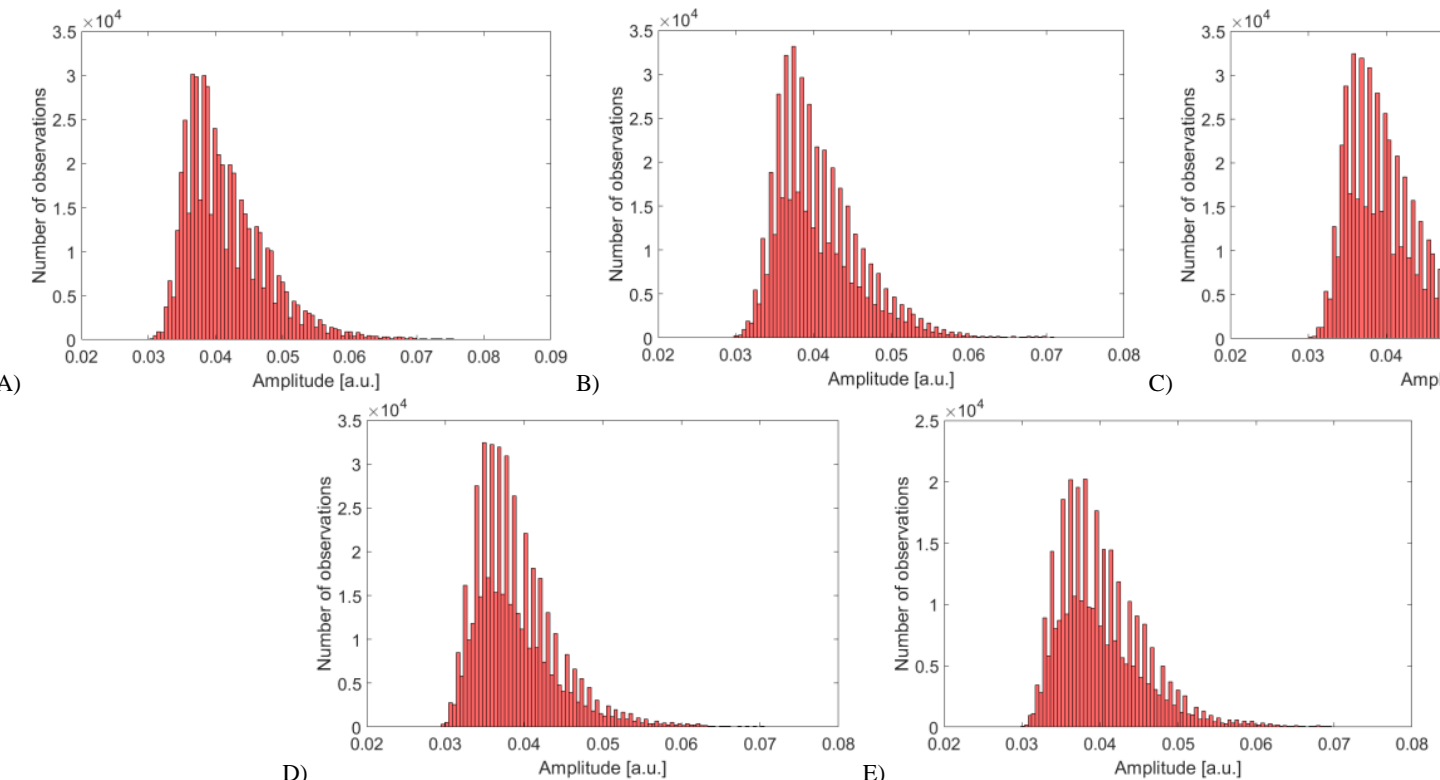

Fig. 3. Histograms of particular 'A'- 'E' areas for $100 \%$ pulverized coal

Table 1. Selected statistical values for particular areas in the course of changes in flame luminosity for pure coal

\begin{tabular}{|c|c|c|c|c|c|}
\hline & Minimum & Maximum & Mean & $\begin{array}{c}\text { Standard } \\
\text { deviation }\end{array}$ & Median \\
\hline A & 0.02947 & 0.08493 & 0.04166 & 0.006223 & 0.0403 \\
\hline B & 0.02882 & 0.07836 & 0.04067 & 0.00525 & 0.03932 \\
\hline C & 0.02882 & 0.07902 & 0.04001 & 0.005295 & 0.03899 \\
\hline D & 0.02816 & 0.07574 & 0.03898 & 0.005419 & 0.038 \\
\hline E & 0.02849 & 0.07574 & 0.005589 & 0.005589 & 0.03899 \\
\hline
\end{tabular}

Table 2. Selected statistical values for particular areas in the course of changes in flame luminosity for a mixture of $80 \%$ pulverized coal and $20 \%$ biomass

\begin{tabular}{|c|c|c|c|c|c|}
\hline & Minimum & Maximum & Mean & $\begin{array}{c}\text { Standard } \\
\text { deviation }\end{array}$ & Median \\
\hline A & 0.01536 & 0.06491 & 0.027 & 0.005775 & 0.02554 \\
\hline B & 0.01733 & 0.06786 & 0.02796 & 0.005981 & 0.02652 \\
\hline C & 0.01635 & 0.07443 & 0.02889 & 0.006059 & 0.0275 \\
\hline D & 0.01766 & 0.07114 & 0.02974 & 0.006584 & 0.02816 \\
\hline E & 0.01602 & 0.07049 & 0.02854 & 0.006515 & 0.02685 \\
\hline
\end{tabular}

to the occurrence of changes in flame luminosity. The graphs were created for 100 time spans. Regardless of the type of combusted fuel, the histograms are characterized by right skewed distribution. Asymmetric distribution may indicate certain disturbances in the process.

In order to better identify the characteristic values, a basic statistical analysis was carried out, determining the parameters shown in Tables 1 and 2. Taking into account the measurement data for pure coal, it should be stated that the highest parameter values, i.e. minimum, maximum, mean, median and standard deviation, were achieved by the 'A' area. In the case of the second variant, it can be observed that the highest values were obtained for the ' $\mathrm{D}$ ' area. The maximum value, achieved in the $\mathrm{C}$ area, constitutes an exception.

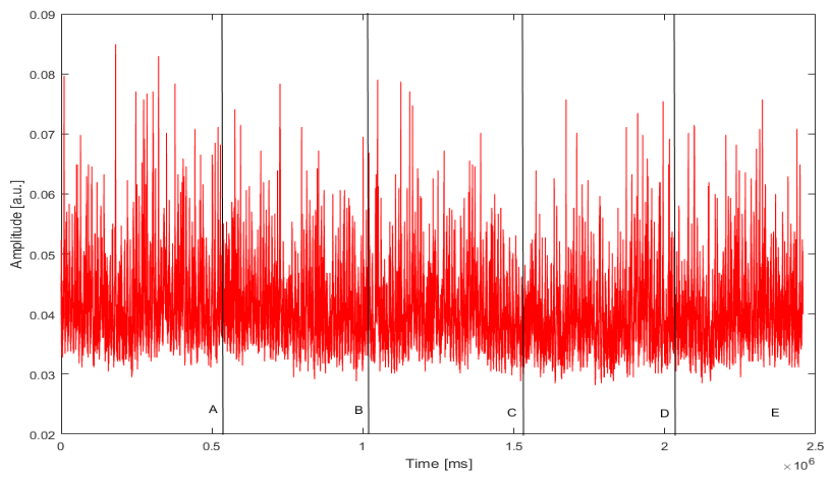

Fig. 2. Measurement of changes in flame luminosity with 'A'-'E' areas for $100 \%$ pulverized coal

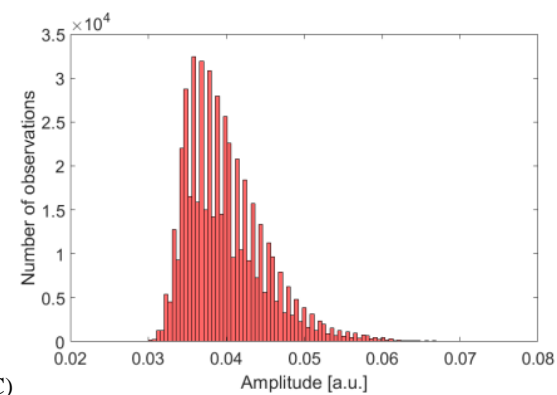

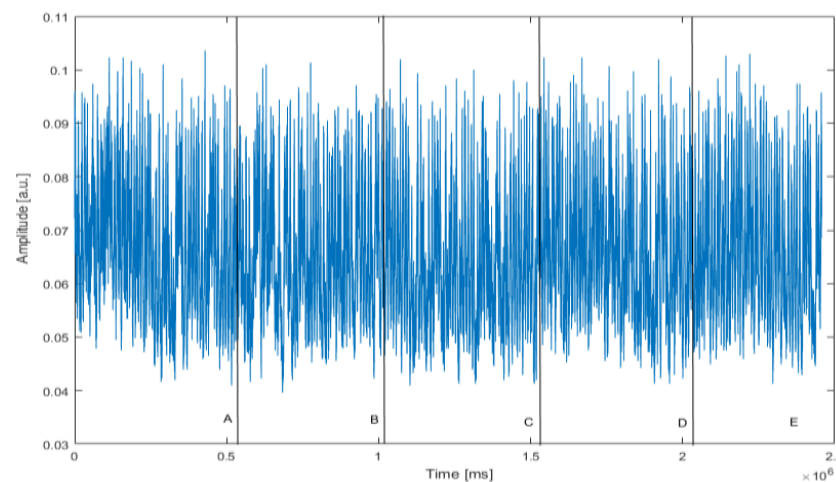

Fig. 4. Measurement of changes in flame luminosity with ' $A$ '- ' $E$ ' areas for a mixture of $80 \%$ pulverized coal and $20 \%$ biomass 

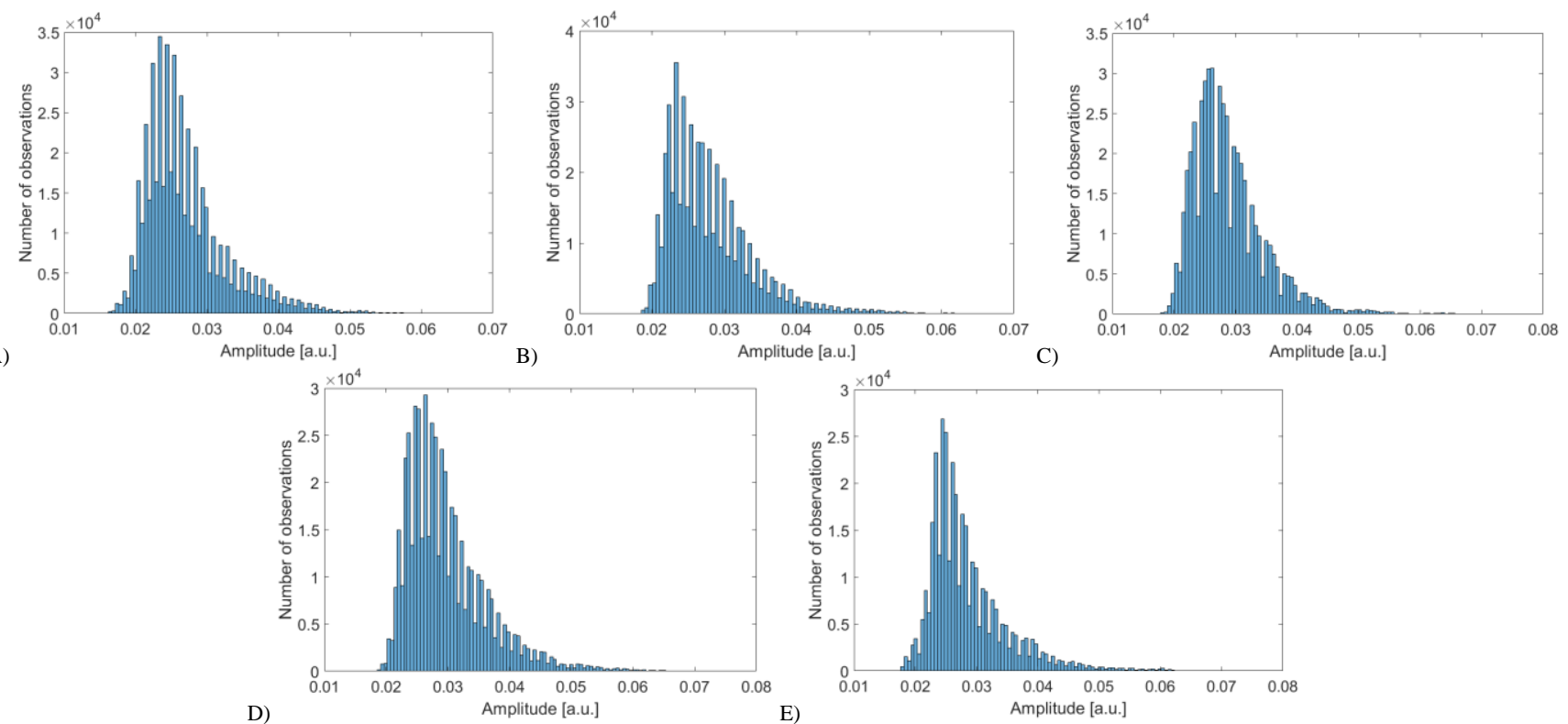

Fig. 5. Histograms of particular 'A'- 'E' areas for a mixture of $80 \%$ pulverized coal and $20 \%$ biomass

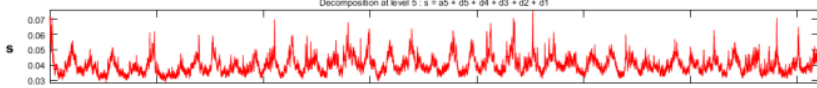

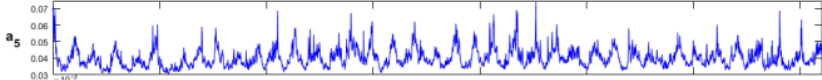
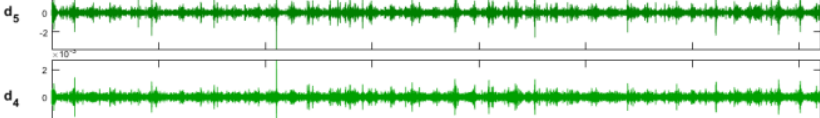

$d_{4}$

Fig. 6. Results of Haar wavelet transform for $100 \%$ pulverized coal
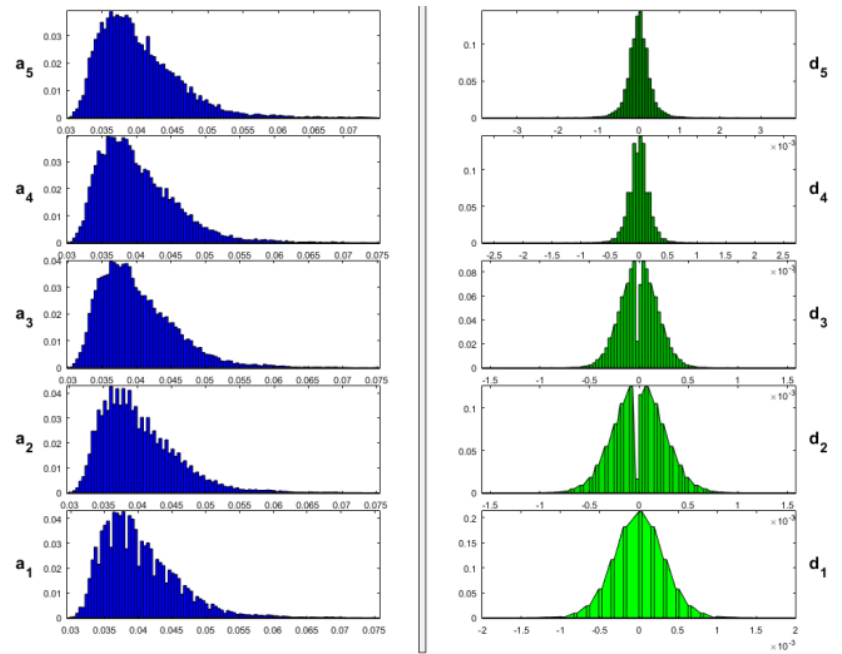

Fig. 7. Histograms of approximation and decomposition following the application of Haar level 5 wavelet transform for pure coal

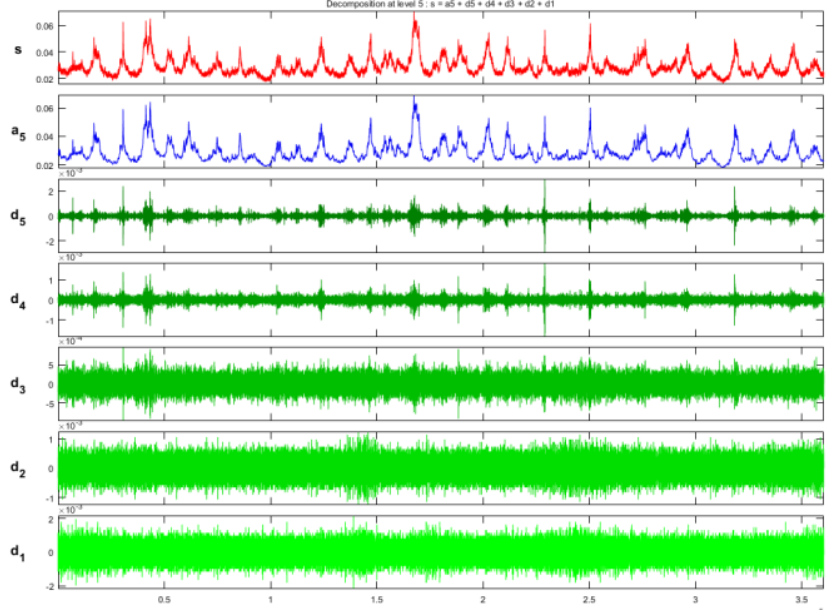

Fig 8. Results of Haar wavelet transform for a mixture of $80 \%$ pulverized coal and $20 \%$ biomass
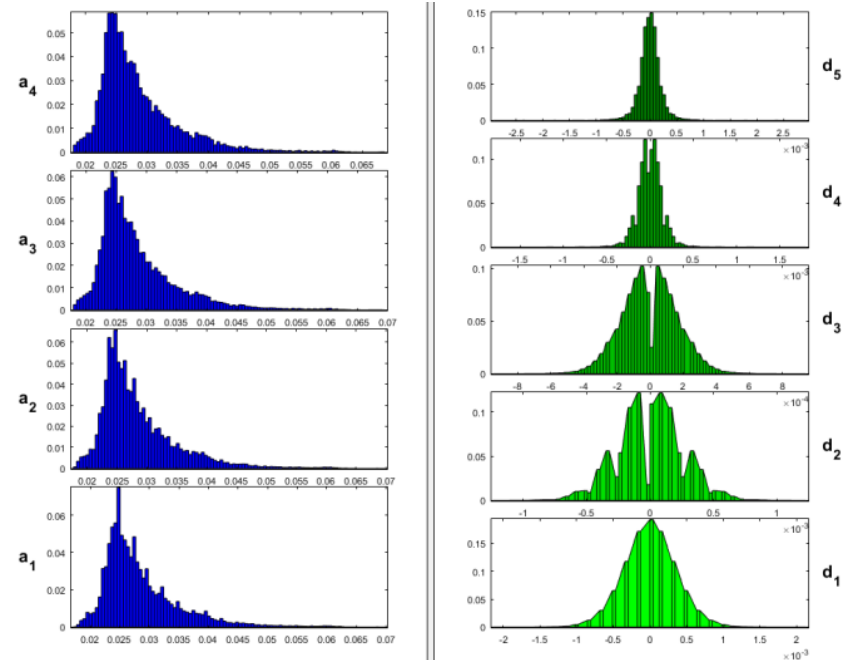

Fig. 9. Histograms of approximation and decomposition following the application of Haar level 5 wavelet transform for a mixture of $80 \%$ pulverized coal and $20 \%$ biomass 
The next step of the measurement data analysis involved the application of a multiresolution analysis based on discrete wavelet transform. The results of test for particular areas - ' $E$ ' for pure coal and ' $\mathrm{E}$ ' for its mixture with biomass - are presented below. Decomposition of basic signals contains approximations and details of the considered signal. Variability pertaining to variable components of low-frequency signals is shown by approximations, while in the case of $d_{1}$ and $d_{2}$ details - for both analyzed variants - they mainly contain high-frequency noise. Figures 6 and 8 show the multiresolution analysis of the investigated signal for pure coal and a mixture of coal with biomass, using Haar level 5 wavelet transform. The figures used symbols such as: $\mathrm{s}$ - original signal, a- approximation and d-detail. The approximation is the approximate value of a signal that is subjected to filtration. The details are differences between the values of the original signal and the approximate values.

While analyzing the courses for both variants presented above, it can be stated that owing to the Haar wavelet transform, the component identification was possible. Conducting multiresolution analysis transformations for the investigated signals enables a precise localization of courses in time. In the case of the data from the combustion of $100 \%$ pulverized coal, the most significant changes can be observed from 0 to $50 \mathrm{~s}$ and from 100 to $250 \mathrm{~s}$. In turn, for the second variant, the greatest changes can be seen from 0 to $50 \mathrm{~s}$ and from 150 to $200 \mathrm{~s}$. It should be observed that the frequency distributions for approximations are characteristic for the right skewed distributions. In turn, the empirical distribution for the decomposition may be considered normal. Both in the case of the data from the combustion of pure coal and its mixture, the graphs were prepared for 100 time spans.

\section{Conclusion}

The complexity of the combustion process requires necessitates employing numerous monitoring and diagnostic methods. The main goal of the process diagnostics involves ensuring optimal process conditions. Optoelectronic monitoring systems in flame diagnostics constitute a tool enabling to acquire detailed information regardless of the conditions, such as high temperature or dustiness. The analysis of measurement signals obtained from a flame should be carried out to account for all variables. The article presented the studies conducted for the combustion process courses recorded by channel 1 of the monitoring system. Tests were performed for two configurations, i.e. pure coal and its mixture (80\%) with biomass $(20 \%)$. The analysis of data was carried out using selected statistical tools and multiresolution analysis. The application of wavelet transform enabled to observe the variability of signals in time. Using the Haar wavelet transform, it was noted that the most significant changes can be observed from 0 to $50 \mathrm{~s}$ and from 100 to $250 \mathrm{~s}$ in the case of pure coal and from 150 to $200 \mathrm{~s}$ for its mixture with biomass. In the statistical assessment of the process, the ' $A$ ' and ' $\mathrm{B}$ ' areas reached the highest values for pure coal and the mixture, respectively. While comparing the combustion process pure coal and its mixture with biomass, it has to be noted that the amplitude is greater for the former.

\section{References}

[1] Ballester J., García-Armingol T.: Diagnostic techniques for the monitoring and control of practical flames. Progress in Energy and Combustion Science 36(4)/2010, 375-411, [DOI: 10.1016/j.pecs.2009.11.005].

[2] Głodek E.: Spalanie i współspalanie biomasy - Przewodnik. Oddział inżynierii materiałowej, procesowej i środowiska, Opole 2010

[3] Kiciński J., Cenian A., Lampart P. et al.: Technologie i urzadzenia zrównoważonej energetyki rozproszonej bazujące na substratach z biomasy $\mathrm{i}$ odpadów rolniczych. IMPPAN, Gdańsk 2015.

[4] Komada P.: Analiza procesu termicznej przeróbki biomasy. Monografie Polska Akademia Nauk. Komitet Inżynierii Środowiska, Warszawa 2019.

[5] Korbicz J., Kościelny J.M., Kowalczuk Z., Cholewa W.: Diagnostyka procesów, Modele, Metody sztucznej inteligencji, Zastosowania. Wydawnictwo NaukowoTechniczne, Warszawa 2002.

[6] Kordylewski W. et al.: Spalanie i Paliwa. Politechnika Wrocławska, Wrocław 2008.

[7] Kotyra A.: Principal component analysis of signals obtained from multichannel flame monitoring system. Przegląd Elektrotechniczny 86(10)/2010, 57-60.

[8] Ozanyan K.B. et al.: All-optoelectronic sensors for combustion-related processes. IEEE Seminar Advanced Sensors and Instrumentation Systems for Combustion Processes 2000, 8/1-8/4, [DOI: 10.1049/ic:20000400].

[9] Sawicki D. et al.: Flame image feature extraction of co-firing coal and biomass with vision diagnostic system. Przegląd Elektrotechniczny 92/2016, 133-136, [DOI 10.15199/48.2016.08.36].

[10] Sawicki D.: Flame monitoring using image classification. Informatyka Automatyka Pomiary w Gospodarce i Ochronie Środowiska 4/2016, 77-80, [DOI: 10.5604/01.3001.0009.5195]

[11] Sawicki D.: Using the GPU to determining the area the flame in the vision diagnostic. Informatyka Automatyka Pomiary w Gospodarce i Ochronie Środowiska 4/2016, 77-80, [DOI: 10.5604/20830157.1148054].

[12] Smolarz A., Kotyra A., Wójcik W., Ballester J.: Advanced diagnostics of industrial pulverized coal burner using optical methods and artificial intelligence. Experimental Thermal And Fluid Science, 43/2012, 82-89 [DOI: 10.1016/j.expthermflusci.2012.04.001].

[13] Wójcik W.: Światłowodowy układ do monitorowania procesu spalania, PAK 53(11)/2007, 24-28.

[14] Wójcik W., Kotyra A., Gromaszek K., Smolarz A., Jagiełło K.: Optical signals based control algorithm for coal combustion proces. Elektronika : konstrukcje technologie zastosowania, 53(6)/2012, 38-40.

[15] Zyska T., Wójcik W., Imanbek B., Zhirnova O.: Diagnostyka stanu czujnika termoelektrycznego w procesie zgazowania biomasy. Rocznik Ochrona Środowiska 18(2016), 652-666.

\begin{abstract}
M.Sc. Eng. Żaklin Grądz
e-mail: z.gradz@pollub.pl

Assistant in the Institute of Electronics and Information Technology of Lublin University of Technology and Ph.D. student at the Electrical Engineering and Computer Science Faculty. Scientific activity includes the analysis of the combustion process in terms of its monitoring and diagnostics.
\end{abstract}

ORCID ID: 0000-0003-1902-4953

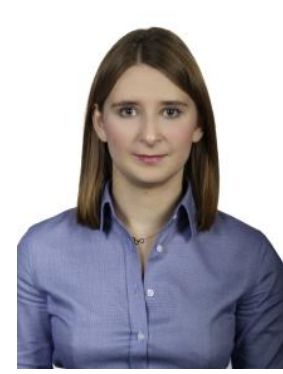

\section{M.Sc.Eng. Joanna Styczeń
e-mail: j.styczen@pollub.pl}

Assistant in the Department of Construction at the Faculty of Building and Architecture of the Lublin University of Technology. Scientific research, includes the impact of zeolites on the cement hydration process and use of zeolites in renovation plasters

ORCID ID: 0000-0001-7325-5045

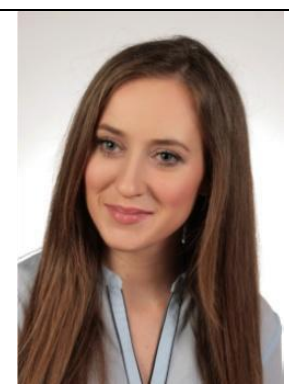

otrzymano/received: 30.05 .2019 przyjęto do druku/accepted: 15.06.2019 